\title{
Race claims spark fury over Croatia's school curriculum
}

Croatian scientists are angry. They believe their science minister is getting schoolteachers to promote the view that Croats are only distantly related to other Slavic populations such as the Serbs.

The claim that there are racial differences between Croats and Slavs is not accepted by geneticists and is potentially incendiary in the Balkan region, recently torn apart by civil war.

Dragan Primorac, minister of science and education, who trained as a medical scientist, denies that he wants the idea taught in schools. "We need much more scientific evidence before we draw conclusions," he told Nature.

But Primorac has regularly upset scientists over the past two years by claiming in newspaper and television interviews that Croats are descended from ancient civilizations that migrated from mid-Asia. The reports quote him as saying that Croats are more similar to Finns than other Slavs.

Last week, discontent boiled over when one of Primorac's advisers, Vladimir Paar, was interviewed by the newspaper Jutarnji List. Paar is a physicist from the University of Zagreb and coordinates the national school curriculum for Primorac. He said that the pilot phase of a new curriculum has just started in $5 \%$ of Croatian schools and includes history classes on the use of scientific techniques, such as genetics, to analyse the distant past of human populations.

In the article, Paar referred to Primorac as "the most competent person in the world" and said: "It is good that kids see that scientific investigations can contribute to human history. Very soon it will be confirmed that Croats are among the oldest nations in Europe and that Hungarians carry more Slavic markers than Croats." However, he told Nature, specific examples like this would not be included in textbooks.

Primorac's arguments are based on data he provided for a Science paper (O. Semino et al. Science 290, 1155-1159; 2000) that looked at a series of genetic markers on the male, Y chromosome of human populations across Europe. The aim of the study was to determine the genetic legacy of palaeolithic Homo sapiens. Primorac has since been reported as saying that the markers in his samples show that Croats are more closely related to Germans and Lapps than to Slavs. These conclusions were not drawn in the Science paper itself.

Geneticists argue against his conclusions on several grounds. For example, only one out of the dozen or so genetic markers analysed revealed that Croats are more similar to northern populations than to other Slavs. "Croatia has a profile of genetic markers similar to the rest of the Balkans," says Ornella Semino, a geneticist at the University of Pavia, Italy, who led the Science study.

Scientists inside Croatia are cautious about engaging in public criticism. But Miroslav Radman, a geneticist born in Croatia and now working at the Necker Institute in Paris, is blunt. "The selection of data to support Primorac's conclusions is appalling," he says. "And to extrapolate so insensitively from sparse evidence is irresponsible."

Alison Abbott

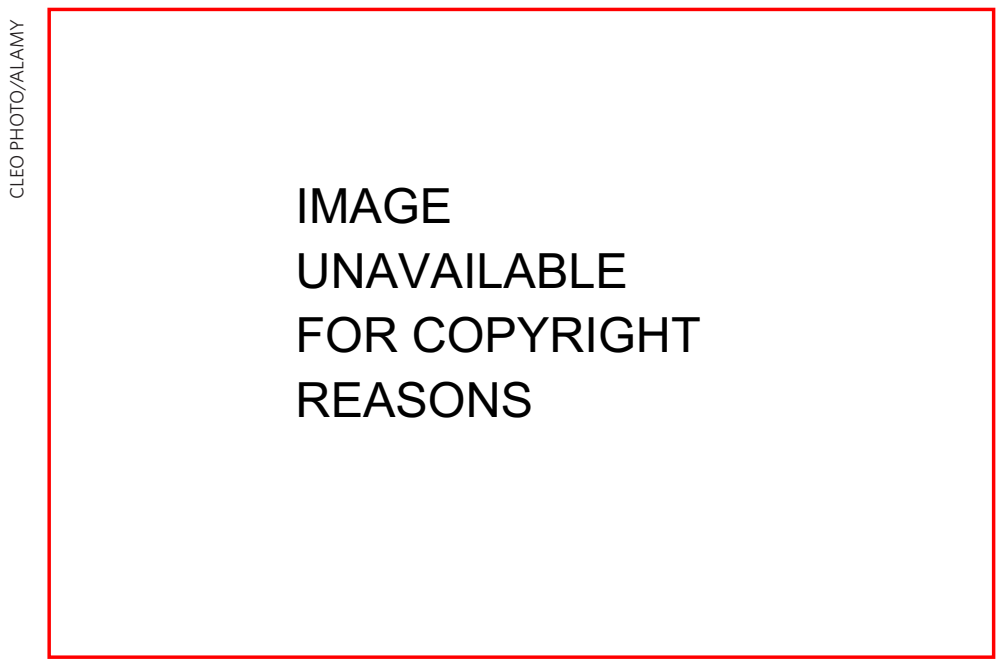

Child care: the teaching of genetics is sensitive in Croatia, given the region's history of racial tension.
ON THE RECORD

(CDelaying having children defies nature and risks heartbreak.")

The British Medical Journal warns women who want children not to defer pregnancy.

\section{c(You have more security at a McDonald's than at some of these facilities.)}

Microbiologist Richard Ebright criticizes security measures at a New Jersey lab that has lost three plague-infected mice.

\section{('Some recipes call for $\mathbf{3 0}$ frogs for a single dish.”}

Biologist Esteban Lavilla describes how local customs are causing frog populations to dwindle in parts of South America.

Sources: Br. Med. J.; Newark Star-Ledger; $B B C$

\section{SCORECARD}

Big brother Dutch authorities plan to track every newborn from cradle to grave - collecting health, family, school and police data in a single electronic source.

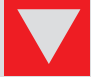
Occupational hazards Office drones and grad students aren't alone: Brazilian farmers who hand-milk their cows risk carpal tunnel syndrome too.

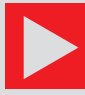
Be prepared US security secretary Michael Chertoff is criticized for attending a bird flu meeting while his agency fumbled to cope with Hurricane Katrina. At least he's ready for one impending disaster.

\section{NUMBER CRUNCH}

$96 \%$ of Americans say it is important to invest in medical research to provide a solid scientific base for health care.

$\mathbf{7 3} \%$ of them do not know that the National Institutes of Health is the agency mainly responsible for funding medical research.

$18 \%$ say they know a scientist personally.

Source: J. Am. Med. Assoc. 